Relations industrielles

Industrial Relations

\title{
Arthur A. SLOANE : Personnel, Managing Human Ressources. Englewood Cliffs, Prentice Hall, 1983, 619 pp., ISBN 0-13-658278-8
}

\section{Paul Tessier}

\section{Volume 39, numéro 4, 1984}

URI : https://id.erudit.org/iderudit/050093ar

DOI : https://doi.org/10.7202/050093ar

Aller au sommaire du numéro

Éditeur(s)

Département des relations industrielles de l'Université Laval

ISSN

0034-379X (imprimé)

1703-8138 (numérique)

Découvrir la revue

Citer ce compte rendu

Tessier, P. (1984). Compte rendu de [Arthur A. SLOANE : Personnel, Managing

Human Ressources. Englewood Cliffs, Prentice Hall, 1983, 619 pp., ISBN

0-13-658278-8]. Relations industrielles / Industrial Relations, 39(4), 804-805.

https://doi.org/10.7202/050093ar

Tous droits réservés @ C Département des relations industrielles de l'Université Laval, 1984
Ce document est protégé par la loi sur le droit d'auteur. L’utilisation des services d'Érudit (y compris la reproduction) est assujettie à sa politique d'utilisation que vous pouvez consulter en ligne.

https://apropos.erudit.org/fr/usagers/politique-dutilisation/ 
and Mail, a wartime federal government bureaucracy largely manned by prominent businessmen who had been recruited by C.D. Howe, 'minister of everything' in the King cabinet, and an Ontario government dominated by northern mining interests. The timing of the strike was unfortunate as well. Not only was a mid-winter strike difficult for the strikers, but gold mining was becoming less profitable as the deepening U.S. involvement in the war made gold less essential for financing the Canadian war effort. There was simply no urgency in getting the men back to work, and the walkout could also provide management with an excuse for reducing staff and closing down less profitable workings while blaming the strike and the union for the subsequent adverse effects upon the economy of the region. The loss of the strike was disastrous for Mine-Mill's operations in the Kirkland Lake district. The turn-around for the union in the district only came (and then slowly) after the enactment of P.C. 1003 in 1944.

This was one of the most serious defeats ever inflicted upon a labour organization in Canada, and its impact was felt throughout the labour movement. Professor Macdowell argues, however, that it was only a defeat in the short run - that it merely marked the low-water mark of labour's fortunes during the war years. The walkout, Macdowell suggests, was the last and most serious of a series of defeats which prompted the labour movement to throw its support behind the C.C.F. in an effort to bring about effective change. The rise in the C.C.F.'s fortunes by 1943, both nationally and in Ontario, made P.C. 1003 and its provincial equivalent, the Ontario Collective Bargaining Act, political necessities which overrode the influence of conservative business and mining interests.

Macdowell's book is a model of what a book of this sort should be. The historical background and the wider social context are well done and provide a concise and up-todate guide to the state of labour relations in Canada before and during World War Two. The story of the strike itself is told with insight and understanding, partly perhaps because the author's father was a participant. This is a first-rate exercise in the 'old' labour history which owes little to the trendy and often marxist-oriented studies in working class culture which are now beginning to appear.

About the only problem is a tendency to inflate the strike's importance: while «remember Kirkland Lake» was undoubtedly a potent slogan during labour's push for P.C. 1003, the author present little evidence that the strike was absolutely crucial to this endeavor. But in terms of the study as a whole this is a minor problem. This book deserves a wide readership among all those interested in the history of modern Canadian labour relations.

\section{Hugh TUCK}

Memorial University of Newfoundland.

Personnel, Managing Human Resources, by Arthur A. Sloane, Englewood Cliffs, N.J., Prentice Hall, 1983, 619 pp., ISBN 0-13-658278-8

Peu de champs d'activités ont subi autant de changements au cours de la dernière décade que celui de la gestion du personnel. Et peu d'auteurs ont fait la synthèse de ces changements avec autant d'à propos qu'Arthur Sloane dans son dernier ouvrage: Personnel, Managing Human Resources.

Reprenant chacun des thèmes inhérents à la gestion des ressources humaines, Sloane, dans un style vivant et direct, fait état des derniers développements. Ainsi traitant de la planification, du recrutement et de la sélection, aborde-t-il aussi le thème de «l'Égalité en emploi», rappelant les lois, règlements, cas juridiques et les efforts qui sont faits aux États-Unis afin de pallier aux injustices auxquelles font face les minorités nationales.

Dans l'introduction, qui forme la première partie de l'ouvrage, Sloane rappelle les étapes qui ont marqué l'évolution de l'administration du personnel aux Etats-Unis. Puis il traite de l'importance de la gestion du 
personnel. «Si la guerre est trop importante pour la laisser aux mains des généraux, rappelle-t-il, il en est de même de la gestion du personnel qui ne doit pas être laissée aux seuls agents de personnel!» D'ailleurs ce livre s'adresse d'abord et avant tout aux gestionnaires. L'auteur leur rappelle constamment que «the name of the game in business is personnel» ou que "Personnel has become the focus of the highest level thinking and policymaking in business».

Sloane traite dans son livre, de façon fort pratique, des problèmes suivants: Comment intégrer son personnel? Comment lui donner une formation initiale adéquate, le recycler? Comment aborder le développement des cadres? Leur plan de carrière? Comment évaluer son personnel de façon à améliorer non seulement leur rendement mais leur motivation et leur satisfaction? Toutes ces questions, et bien d'autres, sont soulevées avec des exemples, des techniques, des approches nouvelles qui font de ce «textbook» un outil fort utile pour tous les gestionnaires.

Deux sections de trois chapitres chacun et de plus de 200 pages abordent des thèmes qui sont souvent escamotés ou tout simplement ignorés dans des ouvrages du même genre. Ces thèmes sont ceux des mol.. de rémunérations, des différents incitatifs monétaires, des avantages sociaux, des systèmes de pensions, de la santé et de la sécurité au travail et enfin de l'attitude que doit avoir le gestionnaire face à la discipline au travail. Sloane ne minimise aucun de ces thèmes qui ont pris au cours des années une importance sans cesse accrue. Il n'est que de signaler l'ampleur qu'ont pris les avantages sociaux avec le temps. De $1 \%$ qu'ils étaient en 1929 , ils représentent plus de $35 \%$ de la rémunération aujourd'hui, avec une croissance annuelle de $1 \%$ ! D'autre part, qui aurait prévu, il y a à peine dix ans, la proportion qu'occupent et qu'occuperont en l'an 2000 , les retraités. Qu'en sera-t-il de leurs pensions? Sloane aborde ce theme avec beaucoup de lucidité et propose des solutions qui ont déjà été éprouvées dans certaines organisations.

Enfin, dans une dernière section, l'auteur présente le thème des relations du travail: une vue d'ensemble de la question, l'évolution des relations patronalesouvrières, la négociation et l'administration des conventions collectives. Cette partie, bien qu'intéressante, ne présente pas le même intérêt que les précédentes. Peut-être, est-ce dû au fait que l'évolution du monde du travail et les luttes syndicales ont pris aux Etats-Unis une ampleur et des tendances différentes des nôtres.

Arthur Sloane termine son ouvrage en invoquant quelques-uns des défis que devront affronter les gestionnaires en matière de gestion du personnel: le respect de la vie privée et des droits des employés, la place des femmes au travail, les burnouts, l'introduction de nouvelles formes et de nouvelles conditions de travail, l'approche devant l'implantation des nouvelles technologies.

En somme un «textbook» de plus de 600 pages qui fait le point sur la gestion des ressources humaines. Un livre qui rend caducs plusieurs de ceux qui ont été écrits récemment. Un manuel qui présente des exemples, des techniques nouvelles, des approches qui ont été utilisées avec succès dans certaines entreprises. Enfin un livre qui, par sa forme, s'adresse non seulement aux étudiants mais aussi à ceux qui leur enseignent!

Paul TESSIER

Ecole nationale d'administration publique Québec

Foundations of Organizational Behavior: An Applied Perspective, by Andrew J. Dubrin, Englewood Cliffs, Prentice-Hall In., 1984, 500 pp., ISBN-0-13-329367-x

Cet ouvrage s'adresse presqu'uniquement aux étudiants de premier cycle universitaire dans les facultés de sciences de l'administration et dans les départements de relations industrielles. Par conséquent, il ne faut pas se surprendre de n'y retrouver que les thèmes largement connus qui constituent le noyau des sciences du comportement formé des éclairages particuliers de la psychologie, de la sociologie et de l'anthropologie appliquées aux organisations de travail. 